\title{
The Effect Of Educational Practices On Nigerian Tertiary Students' Performance In Statistics
}

\author{
Olusegun Ayodele Adelodun \\ Institute of Education, Obafemi Awolowo University \\ Ile-Ife. Nigeria.
}

\begin{abstract}
The study focused on effects of educational practices on tertiary students' performance in statistics. The study aimed at examining the existing relationships between educational activities and affairs, which affects performance of students in statistics. The study adopted a case study research design. The population of the study comprised students of Obafemi Awolowo University, Ile-Ife. The sample of the study was 100 students from five Faculties in Obafemi Awolowo University, Ile-Ife. The sampling technique used was simple random sampling. A self-designed questionnaire was developed and administered to the randomly selected departments for the data collection. The research instrument used for this research was validated by the researcher's supervisor. The questionnaire was personally administered by the researcher. The data obtained was analyzed using descriptive statistics. The findings revealed that majority of the students $90(90 \%)$ agreed that there is relationship between teaching method and tertiary students' performance in statistics, 89(89\%) of the respondents agreed that correlation exists between outcome of assessment using distributed practice homework and massed practice homework. The study also revealed that majority of the students $82(82.0 \%)$ believed that teacher's characteristics affect students' performance in statistics. It was also discovered that a good number of students $\mathbf{7 4 ( 7 4 \% )}$ attested to it that there is significant effect of institutional constraint on performance of students in statistics. The study concluded that there are significant effects of educational practices on the performance of tertiary students in Statistics.
\end{abstract}

Keywords: Tertiary Students; Educational Practices; Statistics Education; Performance; Statistics.

\section{INTRODUCTION}

In a nation with dynamic growing population, the knowledge of Statistics is not only important but applicable in every spheres of the nation. The application of the any acquired knowledge generates commensurate changes which can help improve the quality of the people, society or organization in which it is applied. This is why Statistics is very germane to be studied as a discipline. But compared with other disciplines like Physics, Chemistry, Biology, Agricultural Sciences, Law, among others, Statistics Education is more recent in Nigeria. But it is a reputed discipline in some of the developed nations of the world. According to [1], Statistics Education emerged from two main disciplines: Statistics and Mathematics Education.

However, there is a wide discrepancy in its relevance popularity in some developed countries of the world when compared with its current low standard value in Nigeria. Nigeria is a developing country statistics education in Nigeria is also in its developing stage. The adaptation of statistics education to national needs is inadequate poor, which consequently leads to employment problems for statistics graduates. This problem could be traced to inability of the custodians in the field of Statistics Education distinctly from Mathematics Education. 
In 2002, Garfield and her colleagues in the University of Minnesota, USA began to offer a new area of concentration in Statistics Education that includes course work on teaching Statistics as well as on current research on teaching and learning Statistics. As a matter of fact, Statistical learning should start at earlier stages especially at the secondary school level. In other words, an excellent Statistics educator must not only teach students what Statistics does, but also what it means how it can be applied. Major Universities in Nigeria now offer Master degrees in Statistics, but Statistics is taught at a theoretical level, rarely connected to real world applications unlike in the developed countries. The most important challenge in Statistics Education is to connect Statistical thinking with real-world applications at every level.

Statistics Education is more a recent discipline with peculiar features ([2] in [1]). The knowledge of Statistics Education its multifaceted relevance in human enterprises is a widespread phenomenon in the $1^{\text {st }}$ and $2^{\text {nd }}$ World countries. But in most of the developing countries of the world, including Nigeria, the discipline under study is at its developing stage. Similar to disciplines like Physics, Law, Geology, Accounting, among others, Statistics Education is affected by some educational practices which in turn influences the teaching learning of Statistics, consequently affects the performances of the students.

[3] cites "exponential increases in the amount data the need for graduates and undergraduates to be able to make inferences about the world from data". The report also pointed out questions on whether Calculus is a relevant prerequisite course for STEM undergraduates.

There are several findings which show that several factors affect the academic performance of students at all levels of formal education. These factors could be learners' family background, socio-economic status of the parents, genetic endowment, classroom environment, influence of ICT, instructional materials among others. Little emphasis is placed at present on the influence of educational practices which immensely influence the academic performance of students in their academic affairs.

\section{STATEMENT OF THE PROBLEM}

Various works have been carried out by scholars in the field of Statistics and Mathematics education to examine the existing relationships between various factors affecting the effective learning of Statistics. For instance, researchers have found out that some teachers find it difficult to change their teaching beliefs ([4]). It was discovered in some studies on the relationship between teaching beliefs practice that instructors' beliefs often drive their teaching practices. The need to critically examine the effects of some practices in education which affects performances of tertiary students in the discipline of Statistics, hence the study.

\section{PURPOSE OF THE STUDY}

The aim of this study is to examine the effects of educational practices on student's performances in Statistics as a discipline of study in Obafemi Awolowo University, Ile-Ife. To ensure this, it will be of utmost importance to find out if there is any correlation between educational practices the students' performance in Statistics. The specific purpose of this study is to

- establish the bond of relationship between teaching students' performance in Statistics;

- examine the correlation between outcome of assessment in Statistics using Distributed Practice Mass Practice homework;

- determine teacher Institutional characteristics constraints on students' on students' performance in Statistics; 
- discover the significance of teaching belief on learning, consequently, on students' performance in Statistics.

\section{RESEARCH QUESTIONS}

1. Is there a relationship between teaching method the performance of students in Statistics?

2. Does correlation exist between outcome of assessment using Distributed Practice homework Mass Practice homework?

3. Does the teacher's characteristic affect the students' performance in Statistics?

4. Is there any significant effect of institutional constraints on the performance of students in Statistics?

\section{RESEARCH METHODOLOGY}

The study employed a cluster sampling method. The population comprised students of the Obafemi Awolowo University, Ile-Ife. The sample involved one hundred students from Departments of Mathematics, Demography and Social Statistics, Computer Science, Accounting, among others. They were selected using simple random method. The research made use of questionnaire. Each section of the questionnaire has 10 items each, which constitutes 40 items in total. The respondents are implored to respond to each item using the Likert method of Strongly Agree (S.A), Agree (A), Strongly Disagree (S.D), Disagree (D) Undecided (U). All the data gathered for this study were obtained primarily using questionnaires which were stratified into 5 sub-units. The data collected for the study is analyzed using frequency counts and simple percentage.

\section{RESULTS AND DISCUSSION}

This section presents the results drawn from the data collected. The socio-demographic characteristic of the respondents is provided in Table I:

Table I revealed that $44(44 \%)$ of the respondents were within the age bracket of 19-22 years, $36(36 \%)$ were within the age bracket of $23-26,12(12 \%)$ were within the age bracket of $27-30$ years, 5 were within the age bracket of 15-18 years while 3 were within the age bracket of 3133 years. Also from the table above, 46(46\%) of the respondents were in 300 Level, 39(39\%) were in 400 Level, 12(12\%) were in 200 Level while 3(3\%) were in 100 Level. On departmental level, the table showed that 44(44\%) respondents were from Demography and Social Statistics, 31(31\%) of the respondent were from Mathematics, $6(6 \%)$ were from Accounting, 4(4\%) of the respondents were from Computer Engineering, 3(3\%) were from Mathematics/Integrated Science while $12(12 \%)$ of the respondents were from other departments. It was also revealed that $66(66 \%)$ male respondents $34(34 \%)$ female used in the study. 
Table I: Socio-Demography Characteristics of the Respondents $(n=100)$

\begin{tabular}{|c|c|c|c|}
\hline SN & VARIABLES & $\mathbf{F}$ & $\%$ \\
\hline \multirow[t]{6}{*}{1} & AGE & & \\
\hline & $15-18$ & 5 & 5 \\
\hline & $19-22$ & 44 & 44 \\
\hline & $23-26$ & 36 & 36 \\
\hline & $27-30$ & 12 & 12 \\
\hline & $31-33$ & 3 & 3 \\
\hline \multirow[t]{5}{*}{2} & LEVEL & & \\
\hline & 100 & 3 & 3 \\
\hline & 200 & 12 & 12 \\
\hline & 300 & 46 & 46 \\
\hline & 400 & 39 & 39 \\
\hline \multirow[t]{7}{*}{3} & DEPARTMENT & & \\
\hline & Mathematics & 31 & 31 \\
\hline & Demography Social Statistics & 44 & 44 \\
\hline & Mathematics/Integrated Science & 3 & 3 \\
\hline & Computer Engineering & 4 & 4 \\
\hline & Accounting & 6 & 6 \\
\hline & Others & 12 & 12 \\
\hline \multirow[t]{3}{*}{4} & SEX & & \\
\hline & Male & 66 & 66 \\
\hline & Female & 34 & 34 \\
\hline
\end{tabular}

Research Question 1: Is there a relationship between teaching methods the students' performance in Statistics? 
Table II: Teaching methods Students' Performance

\begin{tabular}{|c|c|c|c|c|c|c|c|c|c|c|}
\hline \multirow[t]{2}{*}{ - 'Items } & \multicolumn{2}{|c|}{$\begin{array}{c}\text { Strongly } \\
\text { Agree }\end{array}$} & \multicolumn{2}{|c|}{ Agree } & \multicolumn{2}{|c|}{$\begin{array}{l}\text { Disagree } \\
-\end{array}$} & \multicolumn{2}{|c|}{$\begin{array}{l}\text { Strongly } \\
\text { Disagree }\end{array}$} & \multicolumn{2}{|c|}{ Undecided } \\
\hline & $\mathrm{F}$ & $\%$ & $\mathrm{~F}$ & $\%$ & $\mathrm{~F}$ & $\%$ & $\mathrm{~F}$ & $\%$ & $\mathrm{~F}$ & $\%$ \\
\hline $\begin{array}{l}\text { Students do not learn well when } \\
\text { teacher does not give room for } \\
\text { students' participation. }\end{array}$ & 42 & 42 & 48 & 48 & 7 & 7 & 1 & 1 & 2 & 2 \\
\hline $\begin{array}{l}\text { Effective learning will be fostered } \\
\text { when teacher utilizes most of the } \\
\text { time stipulated for instruction }\end{array}$ & 27 & 27 & 53 & 53 & 12 & 12 & 8 & 8 & - & - \\
\hline $\begin{array}{l}\text { Statistics is difficult to learn because I } \\
\text { don't always have time to ask } \\
\text { question in areas of difficulty during } \\
\text { teaching/learning process }\end{array}$ & 21 & 21 & 29 & 29 & 26 & 26 & 21 & 21 & 3 & 3 \\
\hline $\begin{array}{l}\text { My knowledge is widened when i } \\
\text { have privilege to interact } \\
\text { meaningfully with the teacher of } \\
\text { Statistics during teaching/learning } \\
\text { process }\end{array}$ & 57 & 57 & 32 & 32 & 4 & 4 & 7 & 7 & - & - \\
\hline $\begin{array}{l}\text { My performance in past statistics } \\
\text { courses are traceable to opportunity i } \\
\text { have to actively participate during } \\
\text { statistics class }\end{array}$ & 39 & 39 & 42 & 42 & 11 & 11 & 6 & 6 & 2 & 2 \\
\hline $\begin{array}{l}\text { There is no difficulty learning } \\
\text { statistics when students are carried } \\
\text { along during teaching/learning } \\
\text { process }\end{array}$ & 46 & 46 & 43 & 43 & 7 & 7 & 3 & 3 & 1 & 1 \\
\hline $\begin{array}{l}\text { Most of the average performances } \\
\text { had in Statistics courses were due to } \\
\text { poor teaching methods }\end{array}$ & 32 & 32 & 28 & 28 & 18 & 18 & 15 & 15 & 7 & 7 \\
\hline $\begin{array}{l}\text { Methods used by the teacher, to great } \\
\text { extent determines the performance of } \\
\text { tertiary students in Statistics }\end{array}$ & 49 & 49 & 40 & 40 & 4 & 4 & 7 & 7 & - & - \\
\hline
\end{tabular}

Table II is the descriptive analysis result to research question one. From the Table, 42(42\%) of the respondent strongly agreed, 48(48\%) respondents agreed, $7(7 \%)$ of the respondents disagreed, $1(1 \%)$ respondent strongly disagreed, while $2(2 \%)$ of the respondents were undecided to item one on the Table. To item 2 on Table II, 27(27\%) of the respondents strongly agreed, 53(53\%) agreed, $12(12 \%)$ disagreed, while $8(8 \%)$ of the respondents agreed. To the third item, 21(21\%) of the respondents strongly agreed, 29(29\%) of the respondents agreed, $26(26 \%)$ of the respondents disagreed, $21(21 \%)$ of the respondents strongly disagreed while $3(3 \%)$ of the respondents were undecided. $57(57 \%)$ of the respondents strongly agreed that their knowledge is widened when they were given privilege to interact meaningfully with the teacher of Statistics during teaching/learning process.

Also, 39(39\%) of the respondents strongly agreed that their performance in past statistics courses were traceable to opportunity they have to actively participate during statistics class, $42(42 \%)$ of the respondents agreed to it, $11(11 \%)$ of the respondents disagreed, $6(6 \%)$ of the respondents strongly disagreed while $2(2 \%)$ of the respondents were undecided. $46(46 \%)$ of the respondents strongly agreed that there is no difficulty learning statistics when students are carried along during teaching/learning process, $43(43 \%)$ of the respondents agreed, $7(7 \%)$ of the respondents disagreed, $3(3 \%)$ of the respondents strongly agreed, while $1(1 \%)$ of the respondents was undecided. 
The table also revealed that $32(32 \%)$ of the respondents strongly agreed that Most of the average performances had in Statistics courses were due to poor teaching methods., 28(28\%) of the respondents agreed, 18(18\%) of the respondents disagreed, $15(15 \%)$ of the respondents strongly disagreed while $7(7 \%)$ of the respondents were undecided. $49(49 \%)$ of the respondents strongly agreed that the methods used by the teacher, to great extent determines the performance of tertiary students in Statistics, $40(40 \%)$ of the respondents agreed, $4(4 \%)$ of the respondents disagreed, while $7(7 \%)$ of the respondents strongly agreed.

Research Question 2: Does correlation exist between outcome of assessment using Distributed Practice homework Mass Practice homework?

Table III is the descriptive analysis of the response to the research question $2.33(33 \%)$ of the respondents strongly agreed that they do better solving questions on a topic at a go, 56(56\%) of the respondents agreed, $4(4 \%)$ of the respondents disagreed, while $3(3 \%)$ of the respondents were undecided. Also, 36(36\%) of the respondents strongly agreed that they like to the problems on similar concepts within a topic, 54(54\%) agreed, 5(5\%) of the respondents disagreed, $4(4 \%)$ of them strongly agreed, while $1(1 \%)$ of the respondents was undecided. Furthermore, $34(34 \%)$ of the respondents strongly agreed that they master the concepts if the practices on it are spread across wide range of topics, $52(52 \% 0$ of the respondents agreed, $7(7 \%)$ of the respondents disagreed, $5(5 \%)$ of the respondents strongly disagreed, while $2(2 \%)$ of the respondents were undecided. Also from the table, $20(20 \%)$ of the respondents strongly agreed that their performance is invariant in any form of practice used in assessment in Statistics, 42(42\%) of the respondents agreed, 14(14\%) of them disagreed, $17(17 \%)$ of the respondents strongly disagreed, while $7(7 \%)$ of the respondents were undecided.

Table III: Correlation between outcome of assessment of Distributed Practice homework and Mass Practice homework?

\begin{tabular}{|l|c|c|c|c|c|c|c|c|c|c|}
\hline \multicolumn{1}{|c|}{} & \multicolumn{2}{l}{\begin{tabular}{l}
\multicolumn{2}{l}{ Strongly } \\
Agree
\end{tabular}} & \multicolumn{2}{l}{ Agree } & \multicolumn{2}{l|}{ Disagree } & \multicolumn{2}{l|}{$\begin{array}{l}\text { Strongly } \\
\text { Disagree }\end{array}$} & \multicolumn{2}{l|}{ Undecided } \\
\cline { 2 - 13 } & $\mathrm{F}$ & $\%$ & $\mathrm{~F}$ & $\%$ & $\mathrm{~F}$ & $\%$ & $\mathrm{~F}$ & $\%$ & $\mathrm{~F}$ & $\%$ \\
\hline $\begin{array}{l}\text { I do better solving questions on a topic at a } \\
\text { go }\end{array}$ & 33 & 33 & 56 & 56 & 4 & 4 & 4 & 4 & 3 & 3 \\
\hline $\begin{array}{l}\text { I like to the several problems on similar } \\
\text { concepts within a topics }\end{array}$ & 36 & 36 & 54 & 54 & 5 & 5 & 4 & 4 & 1 & 1 \\
\hline $\begin{array}{l}\text { I master the concept better if the practices } \\
\text { on it are spread across wide range of } \\
\text { topics }\end{array}$ & 34 & 34 & 52 & 52 & 7 & 7 & 5 & 5 & 2 & 2 \\
\hline $\begin{array}{l}\text { My performance is invariant in any form } \\
\text { of practice used in assessment in Statistics }\end{array}$ & 20 & 20 & 42 & 42 & 14 & 14 & 17 & 17 & 7 & 7 \\
\hline $\begin{array}{l}\text { I tend to forget Statistical concept once i } \\
\text { have been assessed }\end{array}$ & 22 & 22 & 26 & 26 & 24 & 24 & 25 & 25 & 3 & 3 \\
\hline $\begin{array}{l}\text { Both of the method of assessment should } \\
\text { promote students performance in } \\
\text { statistics }\end{array}$ & 28 & 28 & 49 & 49 & 16 & 16 & 4 & 4 & 3 & 3 \\
\hline
\end{tabular}

In addition, 22(22\%) of the respondents strongly agreed that they tend to forget Statistical concept once they have been assessed, 26(26\%) of the respondents agreed, $24(24 \%)$ of the respondents disagreed, $25(25 \%)$ of the respondents strongly disagreed, while $3(3 \%)$ of the respondents were undecided. Likewise, 28(28\%) of the respondents strongly agreed that both of the method of assessment should promote students' performance in statistics, 49(49\%) of the respondents agreed, $16(16 \%)$ of the respondents disagreed, 4(4\%) of strongly disagreed, while $3(3 \%)$ of them were undecided. 
Research Question 3: Does the teacher's characteristic affect the students' performance in Statistics?

From Table IV, 89(89\%) of the respondents supported that educational level of teacher contributes to students' performance in statistics while 11(11\%) said it is false. Majority of the respondent also ticked "true" supporting that the teaching experience of the teacher contributes significantly to tertiary students' statistics performance while 11 respondents ticked "false". 79(79\%) of the respondents said it is true that allocated time for Statistics examination is too small while $21(21 \%)$ of the respondents said it is false. On teacher's mastery of the subject matter, 44(44\%) of the respondents ticked "true" while 56(56\%) of the respondents do not support the statement.

Table IV: Teacher's Characteristics on Students' Performance in Statistics

\begin{tabular}{|c|c|c|c|c|}
\hline \multirow[t]{2}{*}{ - `Items } & \multicolumn{2}{|c|}{$-\quad$ True } & \multicolumn{2}{|c|}{ - False } \\
\hline & $\mathrm{F}$ & $\%$ & $\mathrm{~F}$ & $\%$ \\
\hline Education level of teacher contributes to students' performance in statistics & 89 & 89 & 11 & 11 \\
\hline $\begin{array}{l}\text { The teaching experience of the teacher contributes significantly to tertiary } \\
\text { students' statistics performance }\end{array}$ & 89 & 89 & 11 & 11 \\
\hline The time allocated for Statistics examination is too small & 79 & 79 & 21 & 21 \\
\hline $\begin{array}{l}\text { Teacher's mastery of the subject has nothing to do with student's performance } \\
\text { in Statistics }\end{array}$ & 44 & 44 & 56 & 56 \\
\hline Teacher's behaviour contributes significantly to performance statistics & 89 & 89 & 11 & 11 \\
\hline Good teaching skill promotes performance of students in Statistics & 95 & 95 & 5 & 5 \\
\hline Teacher's competence confidence enhances good performance in Statistics & 95 & 95 & 5 & 5 \\
\hline
\end{tabular}

Moreover, $89(89 \%)$ of the respondents supported the statement that teacher's behaviour contributes significantly to performance statistics, $11(11 \%)$ said it is false. $95(95 \%)$ of the respondents believed that good teaching skill promotes performance of students in Statistics but minutes percentage of the respondents do not. Lastly from the table, it is shown that 95(95\%) of the respondents agreed that teacher's competence and confidence enhance good performance in Statistics but 5(5\%) of the respondents said it is false.

Research Question 4: Is there any significant effect of institutional constraints on the performance of students in Statistics?

Table $\mathrm{V}$ is the descriptive analysis of the responses obtained to the research question 4. From the table, is it revealed that 93(93\%) of the respondents ticked "yes" to the statement that tertiary institution students should have broader knowledge in Statistics than secondary school student but 5(5\%) said no. $84(84 \%)$ of the respondents choose "yes" supporting the expression, "Statistics in University level is tougher than Colleges and Polytechnic Statistics level" while $16(16 \%)$ did not. Also, $80(80 \%)$ believed that policies on duration of time for Statistics do not give what Statistics demands while the remaining percentage did not. $71(71 \%)$ of the respondents supported the statement that there are no adequate materials for effective teaching of Statistics, however, 29(29\%) of the respondents did not.

The table also revealed that $69(69 \%)$ of the respondents agreed that the facility available is not good enough for Statistics teaching, but 31(31\%) of the respondents did not. 
Table V: Institutional Constraints on Performance in Statistics

\begin{tabular}{|c|c|c|c|c|}
\hline \multirow[t]{2}{*}{ - 'Items } & \multicolumn{2}{|c|}{ Yes } & \multicolumn{2}{|c|}{$-\quad$ No } \\
\hline & F & $\%$ & $\mathrm{~F}$ & $\%$ \\
\hline $\begin{array}{l}\text { Tertiary institution students should have broader knowledge in Statistics } \\
\text { than secondary school student }\end{array}$ & 93 & 93 & 7 & 7 \\
\hline $\begin{array}{l}\text { Statistics in University level is tougher than Colleges Polytechnic Statistics } \\
\text { level }\end{array}$ & 84 & 84 & 16 & 16 \\
\hline $\begin{array}{l}\text { Policies on duration of time for Statistics do not give what Statistics } \\
\text { demands }\end{array}$ & 80 & 80 & 20 & 20 \\
\hline There is no adequate materials for effective teaching of Statistics & 71 & 71 & 29 & 29 \\
\hline The facility available is not good enough for Statistics teaching & 69 & 69 & 31 & 31 \\
\hline $\begin{array}{l}\text { Students are put under undue pressure during Statistics teaching evaluation } \\
\text { session }\end{array}$ & 76 & 76 & 24 & 24 \\
\hline $\begin{array}{l}\text { Classroom configuration does not affect the teaching performance in } \\
\text { Statistics }\end{array}$ & 45 & 45 & 55 & 55 \\
\hline
\end{tabular}

$76(76 \%)$ of the respondents choose "yes" to the statement, "Students are put under undue pressure during Statistics teaching evaluation session" while 24(24\%) choose "no". Table 4.5 also revealed that $45(45 \%)$ of the respondents supported the expression that classroom configuration does not affect the teaching performance in Statistics while 55(55\%) of the respondents did not.

\section{CONCLUSION}

As a conclusion to this study, it is revealed that the majority of the respondents said there is relationship between teaching method and the performance of students in Statistics. This implies that teachers of statistics at various educational levels should be mindful of selecting appropriate teaching method to facilitate effective teaching/learning process. It can be also concluded that correlation exist between outcome of assessment using Distributed Practice homework Mass Practice homework. The teacher should employ both methods of assessments. Furthermore, it was concluded that the teacher's characteristic affects the students' performance in Statistics. Finally, the study concluded that there are significant effects of institutional constraints on the performance of tertiary students in Statistics.

\section{RECOMMENDATIONS}

Based on the findings of this study, the following recommendations are made:

- First, the curriculum for teaching Statistics should be reviewed to cater for teaching learning of Statistics from secondary school levels of our educational institutions.

- The Colleges of Education Faculties of Education I all our tertiary institutions should intensify their efforts on imparting the trainee teachers of Statistics on effective methods for teaching Statistics.

- Teachers should make room for effective participation of the learners during Statistics teaching/learning session.

- Teachers should employ both various forms of assessment to enhance mastery of Statistical concepts.

- The student performance will be improving if the administration of the college provides proper leaning facilities to the students also improve the environment of the college.

- Government should have statistics education separately from Mathematics give it due recognition, in fund allocation budget planning.

- There should be in-service training to Statistics teachers' lecturers to foster improvement teachers' proficiencies.

- The University management should provide conducive learning environment provide more lecture rooms. 
- The time allocation for Statistics examination should be commensurate to the difficulty level of the problems.

\section{References}

Adelodun, O.A and Awe, 0.0 (2013): Statistics Education in Nigeria: A Recent Survey. Journal of Education and Practice. Vol.4, No.11

Ben-Zvi, D., Garfield, J. B. (2007): Statistical Literacy, Reasoning Thinking: Goals, Definitions Challenges. In D. BenZvi J. Garfield (Eds.), The Challenge of Developing Statistical Literacy, Reasoning Thinking (pp. 3-15). Dordrecht, The Netherl Kluwer Academic Publishers

National Research Council (2013), “The Mathematical Sciences in 2025,” Washington, D.C.: The National Academies Press.

Zieffler, A., Park, J., Garfield, J., delMas, R., Bjornsdottir, A., (2008), “The Statistics Teaching Inventory: A Survey on Statistics Teachers' Classroom Practices Beliefs," Journal of Statistics Education, 20(1). 